\title{
Needs assessment of income generation training for youths among leprosy families in a leprosy village in Myanmar
}

\author{
Yutaka ISHIDA*1), San SHWE'), Le Le WIN²), Kyaw MYINT ${ }^{3)}$ \\ 1)Bureau of International Cooperation, International Medical Center of Japan, Japan \\ 2)Department of Medical Research (Lower Myanmar), Ministry of Health, Union of Myanmar \\ 3)Department of Health, Ministry of Health, Union of Myanmar
}

[Received: 20 Nov. 2006 / Accepted: 5 April. 2007]

Key words : income generation training, leprosy, Myanmar, needs assessment, stigma

After Myanmar eliminated leprosy in 2003, the prevention of disability (POD), as well as prevention of worsening disabilities (POWD) and rehabilitation became a new agenda, which is one of three national strategies of leprosy control beyond 2005. Since the training needs for income generation for youths living in leprosy villages were not well known, a small-scale survey was conducted in May 2005. This study found that the youths in Mayanchaung village, Yangon Division, were eager to receive training on income generation. After training they wanted to practice and improve their skills with the resources available, because they perceived that a short training course would not enable them to get a proper job. Although they were fully aware of income generation skills, they found it difficult to adequately consider issues such as resources for practicing skills after training, social marketing, and seeking job opportunities. They also felt that mediators could be helpful between villagers and external customers / retailers. On the other hand, the elders, most of whom had disabilities, wanted the youths to stay in the village to take care of them. A basic sewing and stitching training course that was planned to match the study results was produced in January 2006. After 11 months it was observed that a newly opened sewing workshop was busy operating 12 sewing machines because of a big order of making primary school uniforms. How effective the needs assessment was still unknown, but it was found that prior need assessment activities followed by a training course upon the real needs might promote the proper processes of social rehabilitation of youths in a leprosy village of Myanmar.

\section{Introduction}

*Corresponding author:

Bureau of International Cooperation, International Medical

Center of Japan, Ministry of Health, Labour and Welfare,

1-21-1, Toyama, Shinjuku-ku, Tokyo 162-8655, Japan.

TEL : +81-3-3202-7181 FAX : +81-3-3205-7860

E-mail :y-ishida@it.imcj.go.jp
Leprosy is known as a special public health issue due to permanent disabilities and social problems like discrimination and stigma. The WHO has estimated that 2-3 million people are disabled 
because of leprosy"). In Myanmar there are more than 260,000 RFT (Released from Treatment) after WHO/MDT was introduced in 1991 and the disabled with WHO Grade II $^{1)}$ are estimated to be 80,000 among them.' Leprosy elimination, which is defined as registered prevalence rate is below $1 / 10,000$, was achieved at national level at the end of January 2003 in Myanmar ${ }^{2)}$, and the following year the Government established three strategies for leprosy control beyond 2005. The prevention of disability (POD), as well as prevention of worsening disabilities (POWD) and rehabilitation became new one among these strategies, which can reduce socio-economic burden in the community. When the person is a head of household and breadwinner, the family usually faces the economic burden because the PAL is unable to work for regular income. Therefore family members will face not only physical disabilities but also socio-economic burden. According to a previous study conducted in Aunglan Township, Magway Division, Myanmar $^{3}$, leprosy patients-particularly those with grade II disability-needed social and moral support, and also financial support if they were very poor. In these cases other family members need to work for the family ${ }^{5}$. Although there seems to be a great need of social rehabilitation program for PAL and their family members, especially for those who live in leprosy resettlement village, attempts to satisfy the needs are few in Myanmar. For income generating activities, it is essential to build up capacity among leprosy families, particularly youths. For these purposes, either PAL or family members, particularly youths, should be trained in income generation skills ${ }^{6)}$.7). The present study was an attempt to explore training needs for income generation among youths living in a remote leprosy colony in Myanmar, as the outcome of the training was anticipated to be appropriate and useful for them. Through this process, they were expected to become more knowledgeable about income generation activities.

\section{General Objective:}

To explore needs of youths in a rural leprosy village with regard to training in income generation skills.

\section{Specific objectives}

To identify suitable jobs that could generate income for youths

To identify suitable types of training for income generation

To determine the attitudes of the elders (village authorities, health care providers, parents and guardians) towards such training

' Presentation by National Leprosy Control Project at The $8^{\text {th }}$ Leprosy Elimination Co-ordination Committee Meeting, $25^{\text {th }}-26^{\text {th }}$ October, 2006, Yangon, Myanmar

\section{Methods of study}

Qualitative research tools were applied using focus group discussions (FGD) among male and female youths. A total of 7 FGD sessions were conducted for groups that differed according to age and marital status. To identify attitudes towards training, village elders such as village authorities, health care providers, and parents or guardians were asked to give their opinions. Non-participant observation was performed to explore the situation of the village and the economic status of families. Guidelines were set and research assistants were trained; those acting as moderators or taking notes in FGD sessions were of the same gender as participants. Sessions were tape recorded after participants gave informed consent. The note takers transcribed the tape recordings, then the investigators translated the transcripts and performed content analysis using a matrix. 


\section{Findings}

\subsection{Non-participant observation}

- Mayancahung village ${ }^{2}$ is a resettlement village of ex-leprosy patients and their families constructed by the Military Government in 1991. It is situated 25 miles north of Hlegu Township, which is 29 miles from Yangon, the former capital of Myanmar ${ }^{3}$. Surrounding the village is an 82 square mile area that is forested and has a creek. Estimated population is 5000 , consisting of 679 households in 8 wards.

- The village has one middle school; 5-10 PAL have graduated from the school.

- There is one station hospital, which has an outpatients department and a 16-bed inpatient. Medical staff consist of a medical officer, nursing sister, health assistant, and shoe-maker. Like the rest of the village, the hospital has no electricity, and only minor surgery can be performed because there has been no running water for many years. Patients who need intensive medical services are sent to Hlegu (the township capital) civil hospital.

- A dormitory was established for 80 severely disabled leprosy patients; this is run by the Military Government. Patients here have accommodation as well as access to the free meals program arranged by the Social Welfare department and village committee members. An outpatient department treats minor injuries and performs wound dressings for plantar ulcers.

- The village has two Buddhist monasteries, one at the entrance of the village and the other in the middle. There are three Christian churches.

- In the dry season, water supply is mainly from 10 surface tube wells which were dug by the Government; most are no longer functioning. The community has to buy water for domestic use. Rain water is used during the rainy season.
- Vehicular transportation to surrounding areas usually only occurs in the dry season as there is no sealed road to the nearest village 10 miles away. During the rainy season it is hard to reach the village by car, the main means of transport are walking or bicycle, although tractors and motorcycles are also used. The most common prevailing ailments are malaria, diarrhea, and acute respiratory tract infections. Snake bites are also frequently seen.

Research assistants walked around the village to observe patterns of community life. They noted that houses were usually made of bamboo with thatched roofing; very few were of wood with zinc roofing. Some families kept pigs and chicken. Owning a motorcycle was a mark of wealth in the village.

Additional information: Disability survey in Mayanchaung village, March 2004

A disability survey was conducted to identify the magnitude of disabilities among PAL by a joint team of experts from Japan and Myanmar, with the aim of identifying individual needs for physical rehabilitation ${ }^{4}$. Table 1 shows the summary of disability status of those with leprosy disability living in Mayanchaung village $(\mathrm{N}=205)$.

Table 1. Summary of disability status of ex-leprosy patients living in Mayanchaung village ( $\mathrm{N}=205)$ according to WHO disability grade

\begin{tabular}{lccc}
\hline & $\begin{array}{c}\text { Grade } 0 \\
\text { number }(\%)\end{array}$ & $\begin{array}{c}\text { Grade 1 } \\
\text { number (\%) }\end{array}$ & $\begin{array}{c}\text { Grade 2 } \\
\text { number (\%) }\end{array}$ \\
\hline Eye & $171(83.4)$ & - & $34(16.6)$ \\
\hline Hand & $43(21.0)$ & $7(3.4)$ & $155(75.6)$ \\
\hline Foot & $33(16.1)$ & $20(9.8)$ & $152(74.1)$ \\
\hline Overall & $20(9.8)$ & $12(5.9)$ & $173(84.4)$ \\
\hline $\mathrm{n}=205$ & & &
\end{tabular}

${ }^{2}$ There are 5 big leprosy resettlement villages in Myanmar; Susan Haswell Leprosy Home and Hospital, Mawlamyaing, Mon State, run by The Lep- 
rosy Mission, Leprosy Home and Colony, Kyaingtong, Eastern Shan State and Loilem, Southern Shan State both run by RC Mission, Nantharmyaing resettlement village, Mandalay Division and Mayanchaung resettlement village, Yangon Division both run by the Government ${ }^{8}$. Some other small-scale leprosy colonies are also present, for example in Sagaing and Pakokku Township.

${ }^{3}$ The capital of Myanmar was moved from Yangon to a new city "Naypyitaw" under Mandalay Division in Nov. 2005.

${ }^{4}$ Report under preparation

\subsection{Key Informant Interviews (KII)}

A total of six community members of Mayanchaung village (two men and four women, aged between 29 and 70 years) were interviewed to explore the current situation of the village and training needs. Only one, the oldest man, was economically dependent. Two women were primary school teachers, one woman sold groceries and the other made brooms. Educational level varied from primary education to graduate. They were all Buddhists.

\section{Issues identified by the Six Key Informants:}

- Lack of electricity: There is no electricity supply, hence those who cannot afford a generator use battery powered lights or candles.

- Main health issues: Malaria is the commonest health problem and one of the major causes of death.

- Employment: Most people earned money by cutting wood in the nearby forest. Charcoal production is the main job for the majority of villagers. Richer people in the village had provided funds for the equipment used in this process. After the charcoal has been collected, girls sorted the pieces by size and packed them for sale. Men who could travel to Hlegu, the township capital, were paid workers in restaurants and tea shops.

- Social life: the village has a video house. The population is more or less stable as new patients with disability only attended the dormitory.

- Transportation: Transportation is mainly by motor car. However, there is no sealed road to the village, which is therefore is accessible by car only in the dry season. In raining season tractors or carry (Motorcycle) can be used for transportation.

- Previous income generation training: Training in sewing was conducted in 2004 by JICA ${ }^{8)}$. Girls were more interested in sewing training than boys. A voluntary group of writers led by Mr. Chit San Win trained villagers in make up and hair in 2004.

- Training for youths: The oldest man expressed the desire to have a small factory built in the village so that no one needed to leave the village for income. He said that a small factory would do well for youths. Women suggested having sewing training for girls to help them make hand-made products by themselves, which seems to be the most popular training sought by girls. The older women wanted training to sew children's clothes and to embroider other articles. The group mentioned that the most suitable training for boys would be on mechanics so that they could repair cars or motorcycles. They also suggested that the best age for training would be between 15 and 20 years for both sexes.

\subsection{Focus Group Discussions (FGD)}

\subsubsection{Participants in FGD}

A total of 8 FGD sessions were planned to explore the opinions and feelings of the community regarding income generation activities. Four sessions for men and four for women were planned by stratifying participants by age ( $\geq 25$ years old vs. $<25$ years old) and by marital status (single vs. 
married). However, as no men aged over 25 were single, only 7 FGD sessions could be undertaken. A total of 22 men were recruited for 3 FGD sessions. Two trained male research assistants were assigned to each session; one as moderator and the other as note taker. Twenty-nine women were invited for four FGD sessions (Table 2). Group dynamics were balanced by the moderator. While the single women under 25 years old needed to be probed regarding their feelings during discussions, married women aged over 25 tended to discuss issues more actively. Set guidelines were used to lead discussions. Themes of discussions were types of training, technical know how, resources, practical skills after training, arrangements for marketing, and general comments on income generation.

Table 2. Participants of Focus Group Discussions (FGD)

\begin{tabular}{|c|c|c|c|c|}
\hline Sex & $\begin{array}{c}\text { Marial } \\
\text { status }\end{array}$ & No. & Sub-total & Total \\
\hline \multirow{2}{*}{ Male } & Single & 7 & \multirow{2}{*}{22} & \multirow{4}{*}{51} \\
\hline & Married & 15 & & \\
\hline \multirow{2}{*}{ Female } & Single & 11 & \multirow{2}{*}{29} & \\
\hline & Maried & 18 & & \\
\hline
\end{tabular}

\subsubsection{Background characteristics of the study} group

For men's sessions, the study group consisted of men ranging from 18 to 25 years in the younger age group and from 31 to 51 in the older age group. The majority were paid workers doing odd jobs, some transported goods and others sold charcoal. Education level ranged from primary school education to graduate. One single man was a college student, only one man was a graduate, and the majority had attained either $3 \mathrm{rd}$ or 4 th grade schooling. Those who were single (all under 25 years old) lived with their parents, and in most cases, either their father or mother were ex-leprosy patients with deformities. Only a few stated that their grand- mother or grandfather were ex-patients. Two men had moved from other villages, and one of two men explained that he had done so because he found work here and because his mother married a man from the village.

Women participants ranged in age from 14 to 60 years; 11 were single and 18 were married. Educational status ranged from ability to read and write only $(n=1)$ to graduate $(n=3)$; most had reached middle school level (5th, 6th or 7th grade). Sixteen were working, while 13 were dependent. The majority of women sold groceries or charcoal, although 3 women were school teachers. Very few women were economically independent. Most of them lived with either parents, grandparents or close relatives. Either their grandparents or parents had deformities due to leprosy, and the women had accompanied their families who moved from Htaunkkuant, Yangon, where a leprosy hospital had previously been located. Three older women were ex-leprosy patients with deformities of their hands and feet. Those who had deformities were dependent.

\subsubsection{Outcome of FGD Sessions}

All participants agreed that:

- Income generating activities can provide families with a way out of the cycle of poverty.

- Activities should be selected to help families increase their income and improve their standard of living.

- Training is an excellent way of improving chances of getting a job and it gives youth new skills and improves self-confidence.

- Therefore, training for income generation is a requirement for youths, not only to build capacity but also to enhance financial security.

Most participants agreed that:

- Small businesses such as those selling groceries or food, breeding domestic animals, or farming 
vegetables need investment.

- They would like to have proper training, given in their locality, for income generation.

- They were not sure what jobs were appropriate for them; this theme was particularly common in young people of both sex.

For women:

- Both married and single women reported wanting to have an appropriate job for income, but they also mentioned the drawback of living in a relatively isolated area.

- Various income generation activities were explored as follows:

"Animal breeding is good."

"Sewing can be done by both single and married women."

"Curling hair may do well; embroidery is also another possibility for young women."

"Computer training is necessary, as we passed 10th grade."

"Making outfits is a long-term profession, if you have the skills you can do it whenever you want.

For men:

- Both married and single men voiced the idea of breeding pigs or establishing fish ponds. Repairing machines or engines was also mentioned, while some men thought the idea of a barber's service interesting.

Social stigma still existed to some extent in the leprosy colony, even though family members were not themselves affected by the disease. The following statements expressed their low self image.

- The married men mentioned that they did not want to do agricultural work because the products, such as vegetables or fruits, could not all be sold. They said the main reason for this was community reluctance to buy lepers' products.

"We distilled alcohol when we first got here, but the name "Mayanchaung" made people reluctant to buy it, because they knew it was from Mayanchaung (leprosy colony). Because of the name of the village, the alcohol was not accepted by the customers"

$$
\text { (31-year-old married man) }
$$

Similar themes were evident among the women. "We need a factory where we can work. If we have a factory, we do not need to go to other places where we would feel bad about being from Mayanchaung".

(18-year-old single woman)

"We want to have a factory where every villager can work. No investment would be needed for working and we would be employees of the factory. So it would be good for those of us who have no money to invest."

\section{(46-year-old married woman)}

Older single women also responded that they wanted a small factory where they could work as employees; they viewed this as a stable source of income. Young women favored beauty and hair services for women, while older married women liked the idea of a big factory, because both men and women could then work in the same place and there would be no extra transportation cost.

Single women of all ages discussed jobs that could be done within the village. They mentioned that sewing clothes by hand was suitable for girls. They also stated that if they could work at home, there would be no discrimination. Because they had low self image, they were worried about acceptance by other communities.

They agreed that they might need resources like sewing machines for sewing, financial aid for plantation, and investment for breeding pigs or chicken. Equipment and facilities for a workshop were mentioned by the groups. They were aware that their parents could not invest what they needed for income generation. They also acknowledged their lack of access to investment or technical know-how 
(apart from that provided by an organization led by a writer (Mr. Chit San Win)). While they were aware that there are many jobs for young people such as factory work, tailoring, opening or working in a beauty parlor, hairdressing for both sexes, or beauty services for girls, most thought such work impossible because they had low self-confidence due to being family members of PAL.

"I used to sew because I wanted to. If you want to make clothes, you have to develop yourself."

\section{(38-year-old married woman)}

"We want to get training in sewing as we are interested in it. But last year, men were excluded. This is a skill that could help us earn money for our entire lives. We think there will be customers."

\section{(18-year-old single man)}

"I want to be a tailor. Making clothes could be good for housewives too."

\section{(24-year-old married woman)}

A small textile factory was suggested by one men's group; they thought this could provide a job for every youth in the village. However, they did not seem to consider the issues of investment, supply of raw materials or marketing.

Gender specific training was revealed as follows. Male youths preferred training in repairing machines, making furniture, or animal husbandry such as pig breeding. In contrast, female youths wanted training in sewing, hairdressing, beauty services, and planting seasonal fruits and vegetables.

"Training in breeding animals or agricultural work may be good for us; I mean for men. It is good for the long run."

\section{(24-year-old single man)}

"I think sewing training is good for us to get a job for life. You can sew whatever you like. It is good for women."

\section{(17-year-old woman)}

The majority of female participants wanted to open a shop of their own when they were competent after training. They mentioned asking for help from friends to get more customers.

\section{Discussion}

\subsection{Attitudes}

All village elders interviewed agreed with the idea of training for income generation in the village. Sewing training for both sexes was viewed favorably, as suggested by most young men and women. However, some elders preferred sewing training for girls and mechanics training for boys. One man, the village authority, suggested a small factory for the youths based on the fact that he did not prefer the youths to leave the village. Like the young people, the elders seemed to be sensitive about being from leprosy families. They expressed low self-esteem, particularly with regard to marketing. The elders wanted to stay at home while the young ones went out for work. They therefore wanted young men and women to work inside the village and to look after the elders who were housebound.

\subsection{Need for training}

Need for training in order to earn money was discussed in FGD sessions. Jobs repeatedly mentioned were as sewing and embroidery, hairdressing and beauty services for girls, and mechanics, farming, and animal husbandry for boys. The study indicated that the youths as well as the older people wanted training for income generation and were in fact eager to get proper training for the activities mentioned above.

The majority of participants agreed with sewing training for both male and female youths. Tailoring for different clothes was the main interest for training. Making dresses for women was considered a stable income for those seeking jobs. They sug- 
gested that more than two weeks' sewing training would be needed ${ }^{5}$, and that practicing these skills would take further time. They were accordingly concerned about the necessary materials for practice after training.

${ }^{5}$ The duration of the previous training in sewing provided by the JICA project was 2 weeks.

\subsection{Factors for market orientation}

The participants concluded that skills-based training was essential and that resources like money, materials, and manpower were major issues that needed to be addressed in order to get this training. They mentioned that sewing machines for sewing training, equipment and tools for mechanics training, and technical know-how for animal and livestock breeding were indispensable. Marketing of the products made in the village was found to be a big issue as participants felt that they needed someone to liaise with customers. Sustainability was also a factor for those who had already trained, while initiative and motivation were found to be required for those who need training. It would appear that an organization that could develop market orientation was needed.

\subsection{Need for a middleman for marketing}

In FGD sessions, participants also discussed how they could maintain work after training. They preferred an indirect ordering system, because they felt the need for a go-between to liaise with customers and tailors. They thought that with this system they would not need to worry about marketing. Participants were afraid of selling or introducing their products directly to customers or retailers outside the village.

\subsection{Summary of findings in this study}

1. Training in income generation was required for youths in the village
2. Demand for gender-specific training was observed

3. Training in sewing and tailoring was preferred for women

4. Training in mechanics was preferred for men

5. Resources were required for practice after training

6. An indirect social marketing system was required after training

7. Attitudes of the elders toward income generation training differed from those of youths

\section{Follow-up of the study and lessons}

Based on the results of the study, a 12-day long training course on basic sewing and stitching was in January 2006 planned by a study team provided to fulfill the women's needs. Participants consisted of 32 trainees ( 30 women and 2 men), 1 trainer, 4 assistants and 1 supervisor. 23 trainees had the first time experience. An immediate evaluation showed that nobody dropped out, 2 answered that they got a competent skill and other 29 answered that they learned a lot, but much left to be gotten. Through a focus group interview, participants answered that they were much satisfied with the training and got highly motivated. Among their future plans was to be small-scale entrepreneurs. In December 2006 it was observed by a study team that a newly opened sewing workshop was busy operating 12 sewing machines, because of a big order of making primary school uniforms. How effective the needs assessment was still unknown, but it was found that prior need assessment activities followed by a training course upon the real needs might promote the proper processes of social rehabilitation of youths in a leprosy village. 


\section{Acknowledgments}

We would like to express our deep appreciation for all the kind collaboration by members of Mayanchaung village, Hlegu Township, Yangon District, Myanmar. This study was conducted with the technical and financial support of the Leprosy Research Group (Chief: Dr. Mitsuyoshi Maeda, National Suruga Sanatorium, Shizuoka, Japan) of the International Medical Cooperation Research Fund, International Medical Center of Japan (IMCJ), Ministry of Health, Labour and Welfare, Japan.

\section{References}

1) ILEP, Prevention of Disability: Guideline for Leprosy Control Programmes, ILEP Medical Commission, 1993.

2) WHO Regional Office for South-East Asia, Leprosy, Curing patients and preventing suffering and disability, http://w3.whosea.org/leprosy/ preface.htm

3) Lwin K, Myint T, Gyi MM, Thein M et: al Leprosy control in Myanmar 1952-2003 -a success story-Lepr Rev 76: 77-86, 2005.
4) Shwe S, Oo K, Win LL, Sein KN et. al.: Assessment of self image and social needs among grade I and II in Aunglan township, Magway Division, Department of Medical Research, Ministry of Health, Union of Myanmar, April 2003.

5) Ogbeiwi O, Nash J. What would make your life better? A needs analysis of leprosy settlements in the middle belt region of Nigeria. Lepr Rev 70: 295-304, 1999.

6) Walter CS: Social aspects and rehabilitation. International Leprosy Congress, Beijing, 7-12 September 1998. Workshop report. Lepr Rev 70: 85-94, 1999.

7) Chen S, Chu T, Wang Q: Qualitative assessment of social, economic and medical needs for exleprosy patients living in leprosy villages in Shandong Province, The People's Republic of China. Lepr Rev 76: 335-47, 2005.

8) Ko K, Lwin K., Thaing U: Conquest Scourges in Myanmar, Myanmar Academy of Medical Science. 157-159, 2002.

9) Ishida Y, Hikita K. JICA Leprosy Control and Basic Health Services Project in Myanmar. Jap J Lepr 74:185-90, 2005. 


\title{
ミャンマーのハンセン病コロニーにおける 若者に対する職業訓練のニーズアセスメント
}

\author{
石田 裕*1)，San SHWE ${ }^{2)}$ ，LeLe WIN ${ }^{2)}$ ，Kyaw MYINT ${ }^{3)}$ \\ 1 ）国立国際医療センター国際医療協力局 \\ 2) Department of Medical Research (Lower Myanmar), Ministry of Health, Union of Myanmar \\ 3 ) Department of Health, Ministry of Health, Union of Myanmar
}

[受付：2006 年 11 月 20 日、掲載決定：2007 年 4 月 5 日]

キーワード：職業訓練、ニーズアセスメント、ハンセン病、偏見、ミャンマー

ハンセン病による障害の予防・悪化予防とリハビリテーションはミャンマーの三つのハンセン病対策の 戦略の一つである。著者らはハンセン病コロニーに在住している若者達の収入向上の技術研修のニーズを 明らかにするために、調査を行った。この調査から対象のヤンゴン管区マヤンジャウン村の若者達は、何 らかの収入獲得のための技術研修を受けたがっていることが判明した。また彼らは短期間の研修では十分 ではないことを知っており、研修終了後に可能な機会を得て技術を高めるための更なる訓練の機会を得た いと思っていた。彼らは収入向上の技術面は良く理解できたが、しかし、研修後の更なる訓練のための材 料の調達、市場獲得、就職の機会の獲得に関しては、良く想像出来なかった。彼らは、村と外部の顧客や 小売商人の間を取り持つ仲介者が彼らの助けになると考えていた。一方、障害を持つ年寄り達は、若者達 に村にいて彼らの世話をしてくれることを望んでいた。この結果に基づき 12 日間の縫製研修(基礎コース) を行い、32 名が受講した。研修後、村落内に 12 台のミシンで縫製所を新設、小学校の制服の受注し作業 を順調に行っている。ニーズに基づいた研修は、社会的リハビリテーションを促進させる過程で重要であ ることの例と考えられる。

\footnotetext{
* Corresponding author:

国立国際医療センター国際医療協力局

₹ 162-8655 東京都新宿区戸山 1-21-1

TEL : 03-3202-7181 FAX : 03-3205-7860

Mobile : 080-5386-8267

E-mail : y-ishida@it.imej.go.jp
} 